\title{
TOURISM INFRASTRUCTURE, HEALTH AND ENVIRONMENT FOR THE ISLAND OF CRETE
}

\author{
GEORGE MAVRIDOGLOU ${ }^{1}$, THEODORA GIANTSI ${ }^{2}$, BASIL TSELENTIS $^{3}$, \\ KONSTANTINOS ANAGNOSTELOS ${ }^{4} \&$ DIMITRIS PROKOPIOU $^{3}$ \\ ${ }^{1}$ Department of Accounting and Finance, University of Peloponnese, Greece \\ ${ }^{2}$ National Technical University of Athens, Greece \\ ${ }^{3}$ University of Piraeus, Greece \\ ${ }^{4}$ Economist, Greece
}

\begin{abstract}
The concept of carrying capacity in tourism is rooted in the notion of sustainable development. Alternative tourism is a new trend for the structure of the tourism product. Health tourism is related to high-quality services to tourist patients. In this study, we have used environmental and tourism indexes to estimate the impact of tourism to address the structure of the tourism business. We examine the potential opportunities for health tourism as we analyze the port management and development of the island. Crete is the largest island in Greece and concentrates more than 5 million tourists per year. It covers an area of $8,303 \mathrm{~km}^{2}$ and has $170 \mathrm{~km}$ of beaches. There are approximately 630,000 inhabitants in Crete. Tourism supply in Crete includes more than 270,000 beds. The Cretan environment, both natural and manmade, can sustain a polymorphic tourism product for the island. The physical and human environment includes an extended coastline with many sandy beaches, picturesque cities, and traditional villages, unique mountains, wetlands, and lakes.

Keywords: carrying capacity in tourism, coastal zones, and tourism, alternative tourism, health tourism, port management.
\end{abstract}

\section{INTRODUCTION}

The population in Crete is mainly concentrated in the six large towns on the island, the capitals of the old Prefectures, cities of Chania, Rethimno, Heraklion, Agios Nikolaos, and three towns Neapoly, Sitia located in the east coast of the island and Ierapetra in the south coast, the only Greek town in the Libyan Sea (Table 1). The remainder of its inhabitants is principally engaged in rural economies, farming, and livestock raising. After the 1990s traditional lodgings are operated in mountainous villages and tourists have the opportunity to join the traditional living of Crete. Nearly all Cretans, but above all those who live in the market towns and the villages, maintain time-honored customs and manners. Crete is one of the most popular tourist destination in Greece, more than four million international tourist per year visit it. Tourism and agriculture are the two biggest economic sectors in the island (Tables 2 and 3). Tourism facilities in Crete includes more than 270,000 beds which cover the demand.

The objective of this paper is to evaluate the impact of tourism and other business activities on the environment of Crete and to estimate the quality of medical services as alternative tourism offered by the island's infrastructure to highlight the importance of developing long-term sustainable policies. The natural environment plays a major role in determining destination attractiveness [1] in many island destinations. In this study environmental, tourism, and social indices are used to address aspects of this complex interaction between tourism, environment, this leading to highlighting the existing challenges and options, pertinent to the formulation of a specific sustainable tourism development proposal for the island. The contemporary case studies for tourism are focused on the elaboration of the principles of sustainable tourism development, which are to 
Table 1: Population of Crete is increasing from 1981.

\begin{tabular}{|c|c|c|c|c|c|}
\hline Prefecture & Heraklion & Lasithi & Rethimno & Chania & Crete total \\
\hline 1981 & 243,622 & 70,053 & 62,634 & 125,856 & 502,165 \\
\hline 2001 & 292,489 & 76,319 & 81,936 & 150,387 & 601,131 \\
\hline 2011 & 338.052 & 75.995 & 97.059 & 171.822 & 682.928 \\
\hline
\end{tabular}

Table 2: Arrivals in Cretan airports.

\begin{tabular}{|c|c|c|c|c|c|c|}
\hline \multicolumn{7}{|c|}{ Arrivals in Cretan airports } \\
\hline & $\begin{array}{c}\text { Chania International } \\
\text { Airport }\end{array}$ & \multicolumn{2}{c|}{$\begin{array}{c}\text { Heraklion } \\
\text { International Airport }\end{array}$} & Sitia Airport & $\begin{array}{c}\text { Total for } \\
\text { Crete }\end{array}$ \\
\hline & $\begin{array}{c}\text { Arrivals } \\
\text { domestic }\end{array}$ & $\begin{array}{c}\text { Arrivals } \\
\text { abroad }\end{array}$ & $\begin{array}{c}\text { Arrivals } \\
\text { domestic }\end{array}$ & $\begin{array}{c}\text { Arrivals } \\
\text { abroad }\end{array}$ & $\begin{array}{c}\text { Arrivals } \\
\text { Greece }\end{array}$ & $\begin{array}{c}\text { Arrivals } \\
\text { abroad }\end{array}$ \\
\hline 1978 & 153,330 & & 281,469 & 231,180 & & 665,979 \\
\hline 1980 & 152,482 & 5,387 & 266,170 & 386,952 & & 810,991 \\
\hline 1985 & 253,494 & 31,589 & 465,721 & 734,288 & 1,884 & $1,486,976$ \\
\hline 1990 & 155,157 & 173,770 & 298,012 & 926,820 & 1,992 & $1,555,751$ \\
\hline 1995 & 110,777 & 334,118 & 223,649 & $1,559,204$ & 1,459 & $2,229,207$ \\
\hline 2000 & 254,231 & 450,258 & 494,317 & $20,078,233$ & 799 & $21,277,838$ \\
\hline 2005 & 193,179 & 555,647 & 448,461 & $2,003,643$ & 9,032 & $3,210,003$ \\
\hline 2006 & 212,376 & 660,904 & 493,760 & $2,159,452$ & 11,109 & $3,537,601$ \\
\hline 2007 & 248,906 & 683,669 & 537,718 & $2,162,769$ & 17,666 & $3,650,728$ \\
\hline 2008 & 254,659 & 671,477 & 547,484 & $2,154,010$ & 20,000 & $3,647,635$ \\
\hline 2009 & 280,717 & 608,693 & 553,679 & $1,952,074$ & 18,916 & $3,414,079$ \\
\hline 2010 & 227,956 & 593,228 & 504,633 & $1,930,155$ & 19,136 & $3,275,108$ \\
\hline 2011 & 217,817 & 656,791 & 447,279 & $2,161,577$ & 19,029 & $3,502,493$ \\
\hline 2012 & 193,565 & 717,249 & 405,104 & $2,113,501$ & 16,617 & $3,446,036$ \\
\hline 2013 & 185,888 & 849,271 & 409,981 & $2,472,775$ & 15,644 & $3,933,559$ \\
\hline 2014 & 285,611 & 935,615 & 407,162 & $2,595,702$ & 14,767 & $4,238,857$ \\
\hline 2015 & 411,793 & 939,794 & 473,771 & $2,542,914$ & 12,404 & $4,380,676$ \\
\hline 2016 & 436,793 & $1,039,616$ & 503,021 & $2,859,931$ & 9,578 & $4,848,939$ \\
\hline 2017 & 414,851 & $1,105,054$ & 534,647 & $3,120,510$ & 9,808 & $5,184,870$ \\
\hline 2018 & 311,058 & $1,141,589$ & 640,169 & $3,330,492$ & 11,476 & $5,434,784$ \\
\hline
\end{tabular}

Source: Hellenic Civil Aviation Authority.

provide the balance between further development of tourism, international trade, economic interests on the one hand and environmental protection, protection of social and cultural values on the other [2].

In the late 1980s, globally, the concepts of sustainable development received much attention and governments adopted the principles of sustainable development [3]. 


\section{TOURISM}

The tourism development of the island started in the early 1960s in the Northern Part of the island. By 1971, hotels and rooms to rent reached about 20,000 beds, whereas by 2000 the number is estimated at nearly 120,000 beds.

Table 3: Arrivals in Crete airports.

\begin{tabular}{|l|c|c|c|c|c|c|}
\hline International & \multicolumn{3}{|c|}{ Chania } & \multicolumn{3}{c|}{ Heraklion } \\
\hline & 2017 & 2018 & 2019 & 2017 & 2018 & 2019 \\
\hline January & 771 & 5,919 & 1,738 & 4,225 & 4 & 1,738 \\
\hline February & 1,118 & 10,513 & 6,587 & 3,951 & 524 & 6,587 \\
\hline March & 3,794 & 30,130 & 10,228 & 13,823 & 18,674 & 10,228 \\
\hline April & 160,356 & 160,744 & 185,666 & 114,370 & 126,429 & 185,666 \\
\hline May & 374,022 & 433,402 & 402,172 & 257,459 & 305,457 & 402,172 \\
\hline June & 512,666 & 548,220 & 543,179 & 358,690 & 397,248 & 543,179 \\
\hline July & 637,982 & 655,826 & 646,822 & 451,333 & 464,252 & 646,822 \\
\hline August & 627,883 & 649,196 & 651,055 & 411,159 & 427,519 & 651,055 \\
\hline September & 512,853 & 550,345 & 536,058 & 373,931 & 386,533 & 536,058 \\
\hline October & 304,883 & 302,194 & 299,013 & 218,646 & 224,184 & 299,013 \\
\hline November & 11,049 & 18,853 & 16,178 & 3,418 & 6,944 & 16,178 \\
\hline December & 4,249 & 6,455 & 3,471 & 80 & 4,504 & 3,471 \\
\hline & $3,151,626$ & $3,371,797$ & $3,302,167$ & $2,211,085$ & $2,362,272$ & $3,302,167$ \\
\hline
\end{tabular}

In the case of Crete, the number of homes to rent has doubled since the crisis - of the 2,423 homes registered on the platform in 2014 reached 5,100 in 2015 and has since increased at the same rate $(10,298$ in 2016, 16,911 in 2016 and 20,788 in 2018).

\section{CARRYING CAPACITY IN TOURISM}

Sustainable development and its quantification procedure with specialized measurement instrument consist a vital element for the environmental condition of the Greek destinations; as the tourist product is a blend of ecological, social and economic subsystems [4]. For that reason, an adapted amount of sustainable indicators is selected and a comprehensible methodological guide for their use is created, aiming to the reliable measurement of selected parameters [5] that are considered to be important for our region. We believe that using this approach, the local societies and the stakeholders involved as well, can understand the size of the impact on the existing and mainly not renewable resources, to proceed with strategic planning and terms of sustainability for their future developmental course.

Indicators of sustainability point to areas where the links between the economy, environment, and society are weak. They allow you to realize where the problematic areas are and then to suggest the solution policy for each indicator [6]-[8]. The proposed model is based on 16 variables which take values from 0 to 100 , proposed by Losano-Oyola et al. [9] Hadjibiros et al. [10], and Blancas et al. [11]. The sixteen variables measures different issues of sustainability.

The main objective of the first group of variables is the rating of environmental characteristics and infrastructure of the area. This group includes 12 out of 16 variables 
(Table 4) and the score for each one is obtained by using questionnaires and qualitative indicators of each area. The second group consists of four variables (Table 4). The score is derived using quantitative data and quantitative indicators. It should be noted that for quantitative indicators 13-15 high scores correspond to a large burden on the environment and therefore the variable should have low scores in the model.

Table 4: Environmental and infrastructure variables.

\begin{tabular}{|c|l|c|c|c|c|}
\cline { 3 - 6 } \multicolumn{2}{c|}{} & \multicolumn{2}{c|}{ Crete } & \multicolumn{2}{c|}{ Greece } \\
\cline { 3 - 6 } \multicolumn{2}{c|}{} & Mean & St Dev & Mean & St Dev \\
\hline v1 & Urban waste management & 37.18 & 42.37 & 27.94 & 38.94 \\
\hline v2 & Legality of buildings & 58.45 & 47.32 & 54.64 & 46.61 \\
\hline v3 & Protection against noise nuisance & 81.69 & 23.36 & 84.94 & 22.23 \\
\hline v4 & Garbage management & 62.39 & 34.74 & 57.05 & 34.93 \\
\hline v5 & Protection against pesticides usage & 53.38 & 47.72 & 64.64 & 45.38 \\
\hline v6 & Over pumping of sea waters & 86.2 & 30.44 & 77.49 & 37.95 \\
\hline v7 & Sufficient quantity of water resources & 81.83 & 35.19 & 66.77 & 44.15 \\
\hline v8 & Sufficient quality of drinking water & 87.32 & 31.3 & 75.15 & 50.45 \\
\hline v9 & Exposure to forest fires & 68.87 & 40.69 & 71.83 & 40.77 \\
\hline v10 & Land clearing & 83.8 & 35.03 & 80.68 & 36.9 \\
\hline v11 & Conservation of the landscape & 69.86 & 37.74 & 71.79 & 33.41 \\
\hline v12 & Adequacy of green areas & 57.18 & 48.64 & 66.51 & 45.76 \\
\hline v13 & Beds per kilometer of beach & 1166 & 1824 & 763 & 134.7 \\
\hline v14 & Beds per square kilometer & 33.7 & 95.1 & 55.6 & 121.11 \\
\hline v15 & Beds per inhabitant & 0.3604 & 0.7788 & 6.1 & 83.83 \\
\hline v16 & Blue flags per kilometer of beach & 0.518 & 1.153 & 0.036 & 0.7328 \\
\hline
\end{tabular}

For reversal and mapping the value of each indicator onto a 100-grade scale, descriptive analysis was used, extreme values were excluded and minimum tolerable limits for the environmental burden were defined based on environmental literature.

This model can help us to evaluate the policy of the stakeholders and to express infrastructure solutions for each parameter. In the Prokopiou Tselentis model [12], indicators for waste management, pressure on the coastline, illegal building, shore, and marine pollution, and use of freshwater resources have been used to address the sustainability profile of tourist development in the Greek Islands.

Environmental indicators for Crete are presented in Table 4 according to the results for the urban waste management Crete is covered $37.18 \%$. There is protection to the environment against illegal buildings $58.45 \%$ (v2), and protection against the noise 81.69 (v3). Garbage management 62.39 (v4) is cohered from Sanitary Burial as recycling is also taking place.

Protection against pesticides using 53.38 (v5) is implemented. There are no incidents from over pumping in sea waters 86.2 (v6). The quantity of water resources is adequate 81.83 (v7) as also the quality of drinking water $87.32(\mathrm{v} 8)$. There are no fire incidents 68.87 (v9) Incidents of forest clearance 83.8 (v10) happened in tourist areas. The landscape is conserved 69.86 (v11) as green areas are enough 57.18 (v12). The values of the standard deviation in relation to the mean value show the inequality that occurs between the four regions but also within these regions. 
The results indicate that regarding the beds per square kilometres the Crete concentrate more than 1,166 tourists' beds per kilometre of the beach as in the Greek stands this indicator highlights serious coastal pressures. Crete does not have serious pressures as has only 3.7 beds per square kilometre less than the 55.6 of Greek islands. Crete has only 0.36 beds per inhabitant. Regarding the blue flags, the program is developed on the island as is 0.518 blue flags per kilometer of beach in contrast to 0.036 in the rest of the Greek islands.

\section{INTERNATIONAL RETIREMENT MIGRATION}

Large-scale international retirement migration (IRM) to southern Europe is of relatively recent origin. According to Williams et al. [13] there are four main reasons for the overall growth of IRM, the increases in longevity, the decline in the legal age of retirement, an increase in the life flow of earnings and accumulation of wealth so that increasing numbers of individuals have sufficient resources to consider a range of retirement strategies, including international migration and finally the changing patterns of lifetime mobility have provided more knowledge of and experience of living in foreign destinations.

O'Reilly [14] proposed a five-fold typology based on the amount of time spent therein:

- Expatriates: moved permanently; identified as living in the area; may own property; express intention of never returning.

- Residents: resident in terms of home, orientation, and legal status, but spend 2-5 months a year in the country of origin where they either own second homes or visit friends and family.

- Seasonal visitors: live in the country of origin, but return to the destination for 2-6 months each year, in one or more trips; orientated to the home country.

- Returners: usually own second homes; visit irregularly depending on commitments.

- Tourists: identified as being in the area specifically for a holiday; some may own apartments, but most rent space for a short duration.

A variety of factors attract tourists to become permanent residences. Among them:

- Climate;

- An associative and outdoor lifestyle;

- Local hospitality, food, culture;

- Quality and cost of local healthcare;

- Tourism infrastructure, like restaurants, ports, airports, etc.;

- Costs of living and accommodation (at least historically);

- Safety - political stability - taxes;

- Language.

Tourism and migration have a two-way relation, as the retirement emigrants also carry their social networks, which means that they receive visits from friends and relatives every year, the "visiting friends and relatives" (VFR) tourism. Williams et al. [13] estimated that each immigrant brings about seven tourists to the area where he or she lives. On the other hand, repeated holiday visits can act as the stepping stone to seasonal or permanent emigration, often via the purchase of a holiday home. Grete offers everything that someone could want from retirement in Europe. There's marvelous food, rich culture, history, and sunny weather and, it's affordable. There is also high-quality healthcare at a decent price. The biggest challenge for the government is to make easiest the way to take a residence permit. 


\section{HEALTH TOURISM}

Health tourism is a form of thematic tourism, which includes medical tourism, wellness tourism, therapeutic tourism, and spa tourism. The patient decides to travel to receive a specific medical service, motivated by factors such as the cost of the service, its quality, or even the opportunity to combine medical care with leisure.

Archaeological finds show that 5,000 years ago, in ancient Mesopotamia and ancient Greece, people traveled long distances looking for specialized treatments in temples and sanatoriums. The Asclepieia, the oldest Greek hospitals, attracted a large number of foreign patients, who stayed many days in them before returning to their homes and spent a lot of money.

International Medical Travel Tourism mentions that the medical tourism industry worldwide earns 500 million euros of profit per year. Canada, the United Kingdom, Israel, Singapore, and India have dominated the medical field for many years, but during last period countries like Turkey, Egypt, Tunisia, Morocco, countries close to Greece, have been claiming part of this golden market.

According to Table 5, in the four prefectures, there are nine hospitals on the island, with over 2,050 beds, with a bed index/100,000 inhabitants equal to 325,45 units of intensive care, and an index of 7.12 per 100,000 inhabitants. There are, especially in the big urban centers, doctors of all specialties, while the whole island is covered by a wide network of primary care doctors.

Table 5: Health infrastructure.

\begin{tabular}{|l|c|c|c|c|c|}
\hline \multirow{2}{*}{ Category } & \multicolumn{4}{|c|}{ Prefecture } & Total \\
\cline { 2 - 6 } & Chania & Rethymno & Heraklion & Lasithi & \\
\hline Hospital & 2 & 1 & 2 & 4 & 9 \\
\hline Beds & & & & & 2,051 \\
\hline Intensive care unit & 3 & 0 & 3 & 0 & 45 \\
\hline Private clinic & 49 & 29 & 57 & 24 & 159 \\
\hline $\begin{array}{l}\text { First level national health } \\
\text { network }\end{array}$ & 1 & 0 & 6 & 0 & 7 \\
\hline Private medical center & 307 & 109 & 695 & 114 & 1,225 \\
\hline Private doctor office & 30 & 15 & 69 & 17 & 131 \\
\hline Diagnostic health center & 3 & 1 & 3 & 1 & 8 \\
\hline $\begin{array}{l}\text { Hemodialysis and blood } \\
\text { donation }\end{array}$ & 49 & 16 & 71 & 17 & 153 \\
\hline Restore and rehabilitation & 30 & 8 & 15 & 8 & 61 \\
\hline Mental health unit & 7 & 2 & 5 & 3 & 17 \\
\hline $\begin{array}{l}\text { Special care unit (for } \\
\text { disabled patients) }\end{array}$ & 148 & 70 & 294 & 64 & 576 \\
\hline Pharmacy & 145 & 56 & 313 & 61 & 575 \\
\hline Dentist & 158,585 & 87,150 & 310,784 & 74,994 & 631,513 \\
\hline Population & & & & & \\
\hline & & & & & 6 \\
\hline
\end{tabular}


Special reference is made to dialysis units, There are two units of hemodialysis, and private clinics that offer IVF services. There are also three in vitro fertilization units (IVF) in Crete. Their websites are advertised in English, French, Italian, German, Russian, and Turkish. Hundreds of tourists are visiting these units for IVF.

\section{WELLNESS TOURISM}

The tourism industry is continually developing and expanding to meet the needs of changing consumer expectations. According to Tresidder [15] consuming tourism had a link with the associated benefits of health and wellbeing. Defined as "all travel associated with the pursuit of maintaining or enhancing one's personal wellbeing" (Global Wellness Institute, 2020), wellness tourism has recorded remarkable growth in the recent years, making it as one of the fastest-growing market segments in the hospitality and tourism industry. The global wellness economy - which encompasses many industries that enable consumers to incorporate wellness into their lives - is estimated at $\$ 4.5$ trillion in 2017 (Global Wellness Institute, 2020). And wellness tourism is estimated to total $\$ 650$ billion. Spas and wellness centers are becoming important revenue sources for hotels, resorts, and destinations.

Wellness travelers spend more per trip than the average tourist, an international wellness tourist spends 53\% more than the average international tourist and a domestic wellness tourist spends $178 \%$ more than the average domestic tourist. Trihas and Konstantarou [16] research about the spa-goers' characteristics, their majority of them are females, aged 4554 years, married, employed, bachelor's degree holders, with an annual income between $€ 30.001-€ 50.000$ and can be described as experienced and regular spa-goers as approximately. An interesting finding of this study was that it seems that the word "spa" in the name of a resort influences tourists positively to choose the specific resort for their holidays.

Many new investments and marketing initiatives have been launched in recent years, from "the Year of Healthy Waters" promotion in Slovenia, to a Spain-Portugal partnership to jointly promote thermal establishments along their border, the multi-country partnership between Greece, Germany, Hungary, Portugal, France, and Bulgaria, named "Roman Thermal Spas of Europe", to develop and promote thermal tourism packages involving spas and health resorts with a Roman origin. Greece has hot springs that are leading in the Greek tourism promotion, seeking investments to modernize and upgrade thermal offerings.

The challenge for Crete is to participate in these projects with the luxury hotel units in the east of the island and to become an international destination for wellness tourism.

\section{PORTS OF CRETE}

Crete are operating 78 ports currently distributed in the four districts (Fig. 1). According to official data, the $12(46 \%)$ of the ports with berths are located to Chania district, $8(31 \%)$ to Rethymno, 3 (11\%) to Lathishi and 3, (11\%) to Heraklio (Fig. 2). The most and the major of them, $53 \%$ or $68 \%$ of total, are located on the north coast of the Island viewing the South Aegean Sea, as it is more populated and related to continental Greece. Only 25 (32\% of the total) port facilities are located on the south coast of the island viewing the Libyan Sea. (Fig. 3). Most of the Port facilities in Crete provide services to different users (Table 6). According to our data (Fig. 4) 14 ports (18\%) provide services to passengers, 52 ports $(67 \%)$ used and for fishing boats and 26 ports $(33 \%)$ have yachts facilities. But the reality is little different, because only one marina exists in Lasithi (Ag. Nikolaos) providing quality services for 255 yachts. Berths for yachts also exist at the Port of Heraklion (200 berths) and the marina of Rethymno (170 berths). 


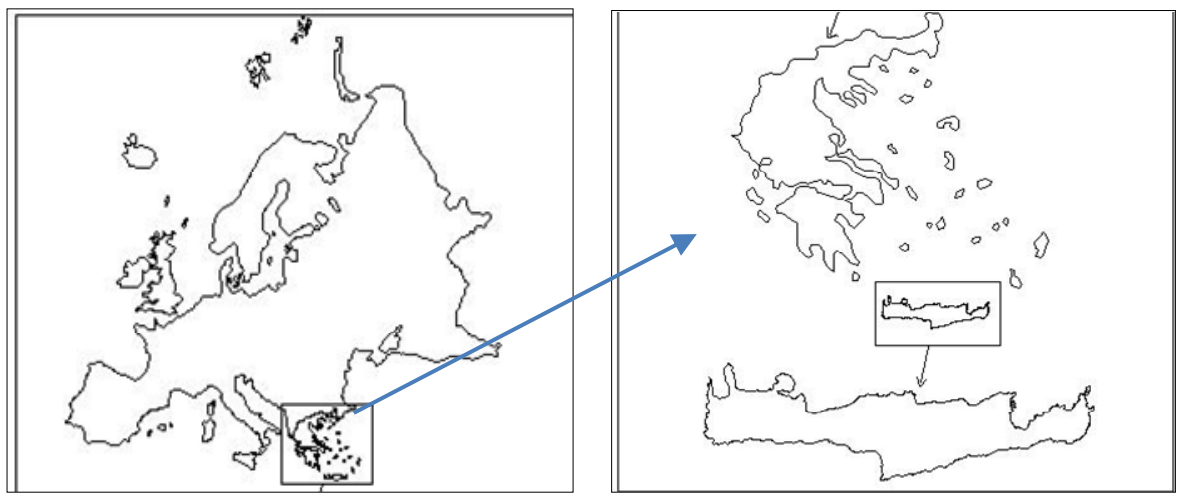

Figure 1: Europe, Greece and Crete.
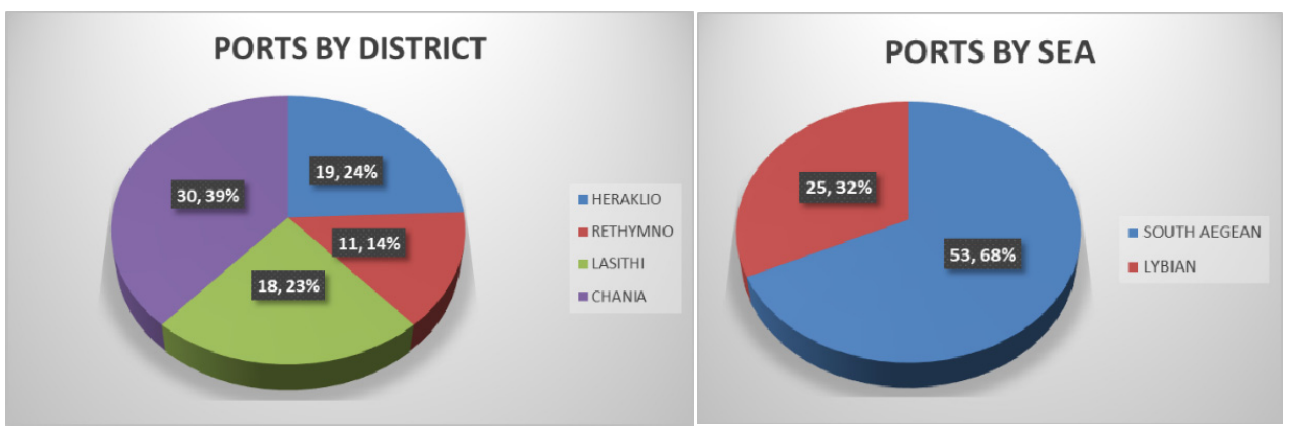

Figure 2: Distribution of Cretan Port by Figure 3: Distribution of Cretan Port by district (number of ports, percentage). (Source: Analysis by sea (number of ports, the authors.) percentage).

Table 6: Passengers port lines.

\begin{tabular}{|c|c|c|c|c|c|}
\hline${ }_{\text {Port }}^{\text {Service }}$ & Cruise & $\begin{array}{l}\text { Daily } \\
\text { cruise }\end{array}$ & $\begin{array}{l}\text { Coastal } \\
\text { shipping }\end{array}$ & $\begin{array}{l}\text { Service } \\
\text { Port }\end{array}$ & $\begin{array}{l}\text { Ferries } \\
\text { (South } \\
\text { Chania) }\end{array}$ \\
\hline Heraklio & $X$ & & $X$ & Ag. Roumeli & $\mathrm{X}$ \\
\hline Chania (souda) & $\mathrm{X}$ & & $\mathrm{X}$ & Gavdos & $\mathrm{X}$ \\
\hline Ag. Nikolaos & $\mathrm{X}$ & $\mathrm{X}$ & $X$ & Chora Sfakion & $\mathrm{X}$ \\
\hline Rethymno & $\mathrm{X}$ & $\mathrm{X}$ & $\mathrm{X}$ & Loutro & $\mathrm{X}$ \\
\hline Siteia & $\mathrm{X}$ & & $X$ & Sougia & $\mathrm{X}$ \\
\hline Kissamos & & $\mathrm{X}$ & $X$ & Paliochora & $\mathrm{X}$ \\
\hline Chersonissos & & $\mathrm{X}$ & & & \\
\hline Ierapetra & & $\mathrm{X}$ & & & \\
\hline
\end{tabular}




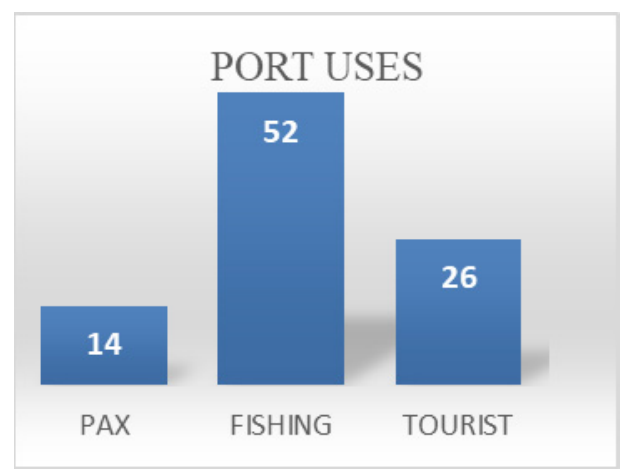

Figure 4: Port uses.

We have to mention that in South Chania area, the Ferry line connect villages with very difficult road access or even no access like Loutro, or the island of Gavdos.

There is also some private marinas related to hotels. All the other facilities are simply shelters for small boats of pleasure. Aerial views of (a) Ag. Galini Marina, (b) Paliochora Marina, and (c) the port of Chania city are presented in Fig. 5.

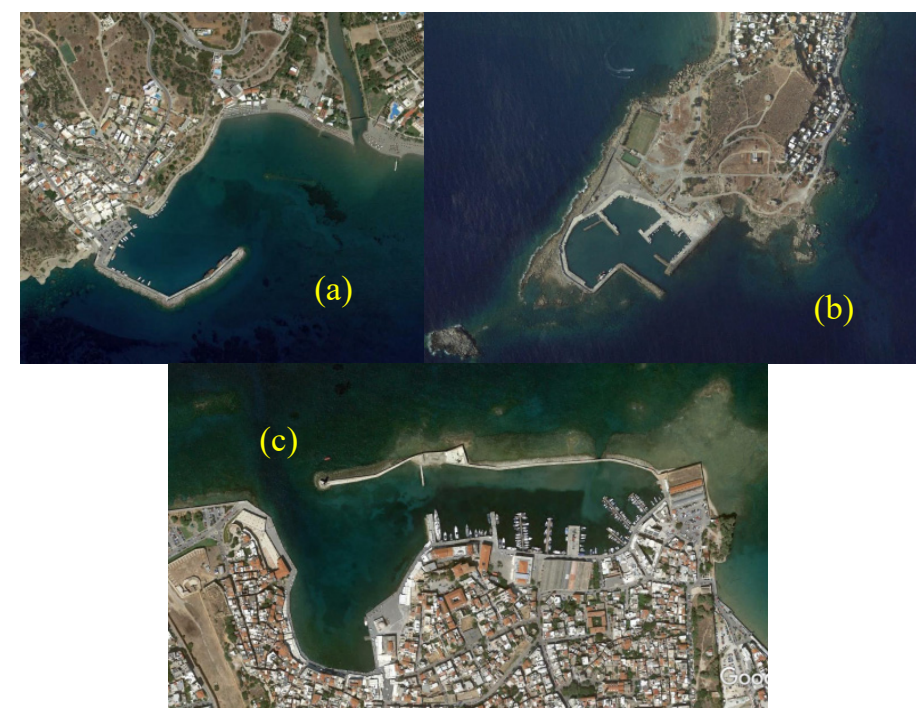

Figure 5: Aerial views. (a) Ag. Galini Marina; (b) Paliochora Marina; and (c) The port of Chania.

Cruise ships have visited six Cretan ports during recent years and one of them (Heraklion) is also Home Port. According to data provided by the Hellenic Ports Association, after some years of stagnation, a significant increase in calls and passengers arrivals is observed during 2019 (Fig. 6). Heraklion and Souda (Chania) are the most popular destinations. On the other hand, the number of coastal shipping passengers is stable 
during recent years (Fig. 7). Also, Heraklion and Chania accept the most of passengers. The competition between ships and planes is present. For the line of ferries in South Chania, a significant decrease in passengers is observed after 2010.
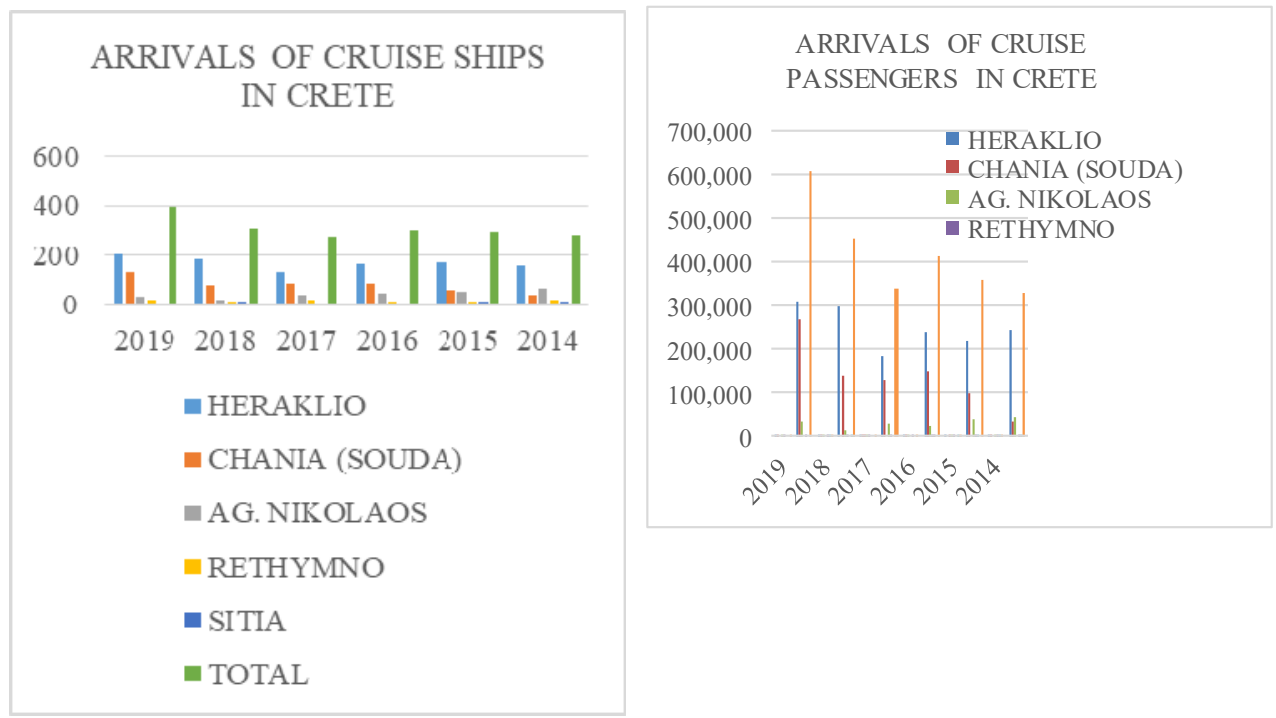

Figure 6: Arrivals of cruise ships and cruise passengers in Crete. (Source: Hellenic Ports Association (www.elime.gr/krouaziera).)
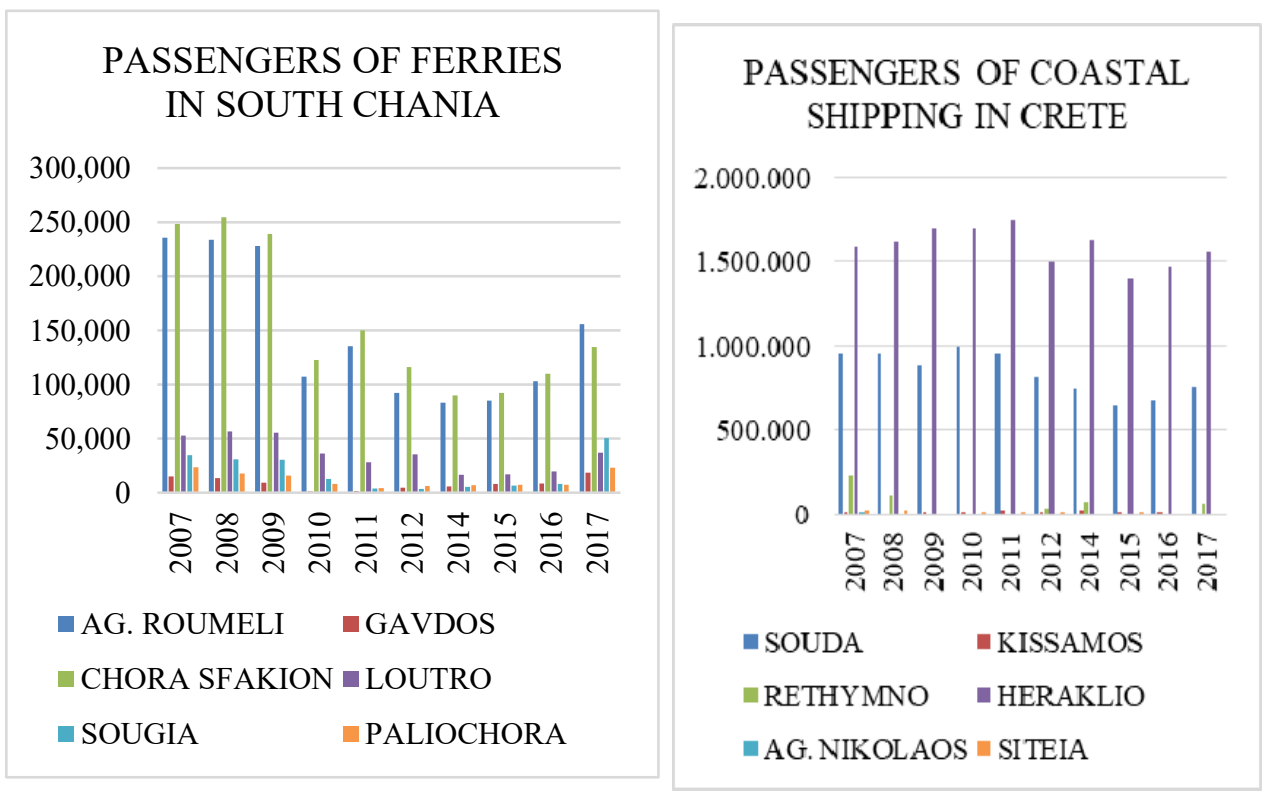

Figure 7: Passengers of coastal shipping and ferries in South Chania. (Source: Hellenic Statistical Authority (www.statistics.gr/el/statistics/-/publication/SMA06/-).) 
A network of marinas and shelters in the north and the south coasts of Crete will make Crete a new destination for these users. In Crete, there are big opportunities to improve the touristic product via the development of the ports.

\section{CONCLUSIONS: PROPOSALS}

Tourism via seaports can be divided into Cruise, Daily Cruise, Coastal Shipping-Ferries, and Yachting. For the Cruise industry, Crete is a perfect destination with a strong brand name. An improvement of the existing infrastructures and provided services will awake the real potential in that sector.

Daily Cruise in Crete is not enough developed and can be improved. No special needs in port infrastructures are needed. Ferries in the South Chania can also be related to this kind of tourism.

Coastal shipping is always under the pressure of the airplanes' competition, but always is a vivid need for the connection of the island with continental Greece and other islands. To ameliorate yachting a generous improvement of the tourist port infrastructure is needed. New marinas will be constructed, especially in Heraklion, providing high-level services in this sector.

Crete, one of the most popular tourist destinations, has all the supplies to develop and value this valuable branch of medical tourism, taking advantage of its high standard hotel units and upgrading existing hospitals, doctors, and health centers.

Completion of urban waste treatment plants and networks, protection against pesticide usage, and adequacy of green areas must be in progress, as there is still a lack of efficiency. The current health crisis of the COVID-19 pandemic expansion, has had the tourism market as a major victim. The return to normalcy after the lockdowns will significantly change the way people think and their priorities. New opportunities arise for destinations that meet the new requirements of tourists, which concern the health services of tourist destinations as well as the possibility of non-cohesion of tourists.

Crete is the fifth largest island in the Mediterranean, important tourist infrastructures have a sunny Mediterranean climate and a long summer. Also, there is a significant number of hospitals, clinics, and a wide network of private doctors.

Taking into account the above, Crete haw the opportunity to increase the tourist season, proposing to people who have the opportunity, such as retirees, to transfer their vacation in September or October to reduce the congestion in the area.

Many Europeans, under the fear of a new lockdown, will decide to travel and pass the following autumn and winter out of the cities, to a place where they can walk, exercise, and feel better. Crete can be this place so a campaign to attract people for long-term vacations or immigration after retirement.

\section{REFERENCES}

[1] Charlie, C., Pearlman, M. \& King, B., A conceptual framework for environmental governance networks: An analysis of small island destinations in Indonesia and the Coral Triangle. Sustainable Tourism V, WIT Transactions on Ecology and the Environment, vol. 151, WIT Press: Southampton and Boston, 2012.

[2] Skripnuk, D., Kikkas, K. \& Dinenko, N., Trend analysis of the international tourist services market. Sustainable Development and Planning VII, WIT Transactions on Ecology and the Environment, vol. 193, WIT Press: Southampton and Boston, 2015.

[3] Sustainability and the traditional tourism model in Baja California Sur, Mexico. Sustainable Tourism V, WIT Transactions on Ecology and the Environment, vol. 151, WIT Press, Southampton and Boston, 2012. 
[4] Zannou, V., Guide of Socio-Economic Studies for the Integrated Management of the Water Environment, 1999.

[5] Bimonte, S., Sustainable tourism and management tools. Sustainable Tourism II, WIT Press: Southampton and Boston, 2006.

[6] Hammond, A., Adriaanse, A., Rodenbourg, E., Bryant, D. \& Woodward R., Environmental Indicators! A Systematic Approach to Measuring and Reporting on Environmental Policy Performance in the Context of Sustainable Development, World Resources Institute, 1995.

[7] Hadjibiros, K., Aravantinou, M. \& Lapsidou, C., Organization and evaluation of a sustainable island network. Sustainable Development and Planning, 6(1), 2011.

[8] Stein, I., Riley, J. \& Halberg, N., Issues of scale for environmental indicators. Agriculture, Ecosystems and Environment, 87, pp. 215-232, 2001.

[9] Losano-Oyola, M., Janvier-Blancas, F., Gonzalez, R. \& Caballero, M., Sustainable tourism indicators as planning tools in cultural destinations. Ecological Indicators, 18, pp. 659-675, 2012.

[10] Hadjibiros, K., Aravantinou, M. \& Lapsidou, C., Organization and evaluation of a sustainable island network. International Journal of Sustainable Development and Planning, 6(1), pp. 13-20, 2011.

[11] Blancas, F.J., Gonzalez, M., Lozano-Oyola, M. \& Perez, F., The assessment of sustainable tourism: Application to Spanish coastal destinations. International Journal of Ecological Indicators, 10, 2010.

[12] Prokopiou, D.G., Environmental management of coastal zones and tourism. PhD dissertation, University of Piraeus, Piraeus, Greece, 2019.

[13] Williams, A.M., King, R., Warnes, A. \& Patterson, G., Tourism and international retirement migration: New forms of an old relationship in southern Europe. Tourism Geographies: An International Journal of Tourism Space, Place and Environment, 2(1), pp. 28-49, 2000. DOI: 10.1080/146166800363439.

[14] O'Reilly, K., A new trend in European migration: Contemporary British migration to Fuengirola, Costa del Sol. Geographical Viewpoint, 23, pp. 25-36, 1995.

[15] Tresidder, R., Health and medical tourism. Research Themes in Tourism, eds P. Robinson, S. Heitmann \& P. Dieke, CABI: Oxfordshire, pp. 266-275, 2011.

[16] Trihas, N. \& Konstantarou, A., Spa-goers' characteristics, motivations, preferences, and perceptions: Evidence from Elounda, Crete. Alma Tourism, 14, 2016.

DOI: 10.6092/issn.2036-5195/6300. 